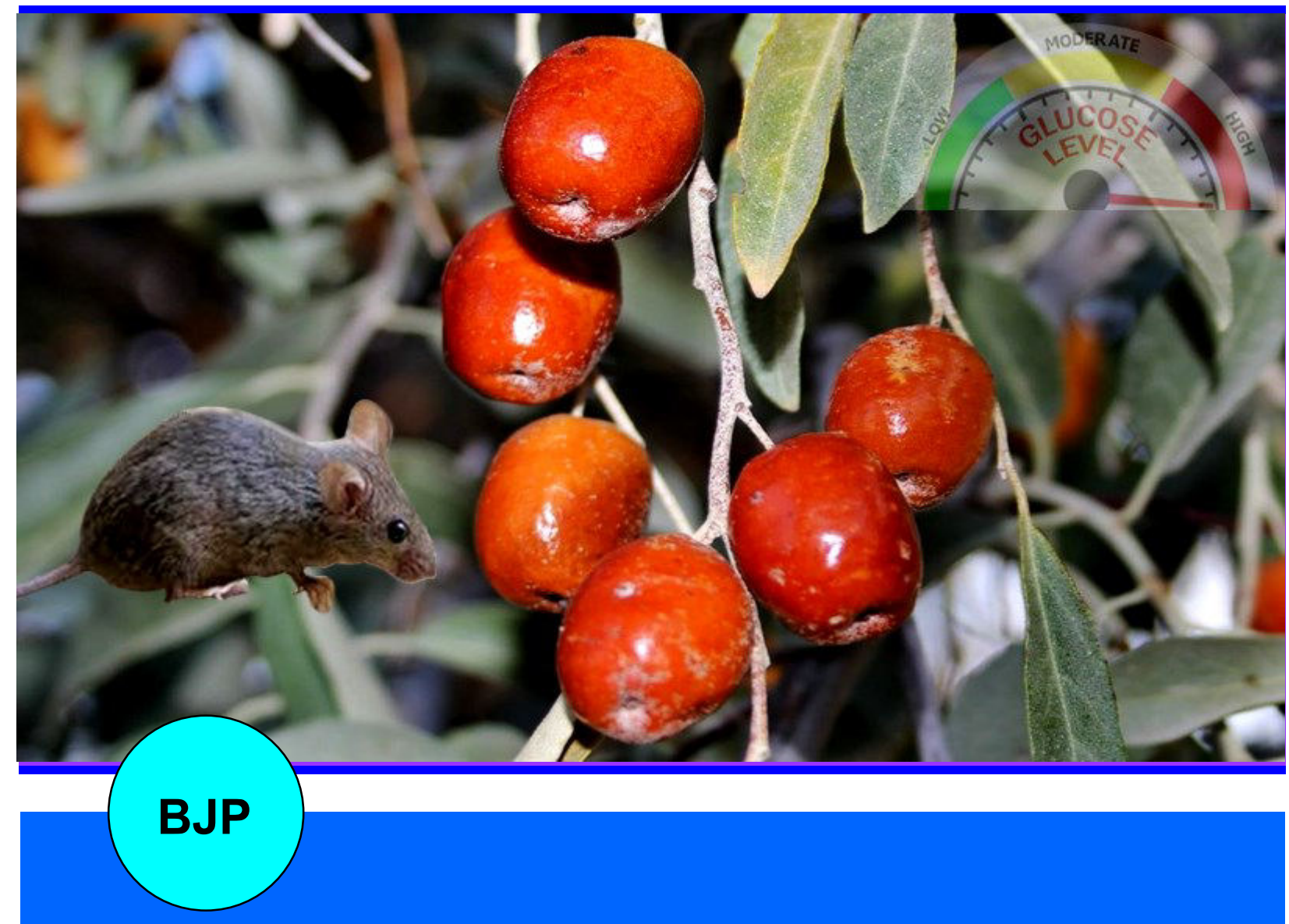

Bangladesh Journal of Pharmacology

Research Article

Hypoglycemic potential of Elaeagnus angustifolia fruit polysaccharide on streptozotocin-induced type 2 diabetic mice 


\section{Hypoglycemic potential of Elaeagnus angustifolia fruit polysaccharide on streptozotocin-induced type 2 diabetic mice}

\section{Ya Wang, Hong Mei Zou, Cui Sun, Tao Guo and Zai Ping Feng}

School of Life Science and Engineering, Lanzhou University of Technology, Lan Gong Ping Street 287, Lanzhou 730050, China.

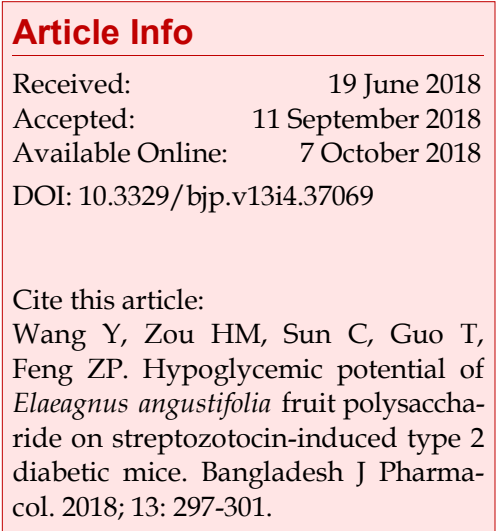

\begin{abstract}
In this study, the hyperglycemic potential of Elaeagnus angustifolia fruit polysaccharide in both normal healthy and streptozotocin-induced diabetic mice was investigated. Results showed no significant effect of E. angustifolia fruit polysaccharide on blood glucose level in normal control group, while $E$. angustifolia significantly suppressed the rise in blood glucose of diabetic mice. In addition, in the first two weeks of administration, the body weight was decreased both in negative control group and E. angustifolia groups, however, E. angustifolia $(800 \mathrm{mg} / \mathrm{kg})$ was recovered to the begining weight in the fourth week. E. angustifolia $(800 \mathrm{mg} / \mathrm{kg})$ could markedly reduce the levels of total cholesterol, triglyceride and improve the level of high density lipoprotein-cholesterol. The results suggest that E. angustifolia could be considered as an ingredient of functional foods for diabetes.
\end{abstract}

\section{Introduction}

Diabetes is a metabolic disease which has the characteristic of hyperglycemia. With the development of the society and the improvement of people's living standard, the incidence of diabetes also rises sharply $(\mathrm{Li}$ et al., 2007; Kim et al., 2010). It is necessary to find an effective and low-toxicity hypoglycemic drug.

For the past few years, numerous extracts have been isolated from plant and used as a promising source of therapeutic agents for diabetes mellitus such as Coptis chinensis (Jiang et al., 2013), Rhizophora mangle cortex (Andrade-Cetto et al., 2017), Lilium lancifolium (Zhang et al., 2014), pumpkin (Wang et al., 2017a), peach gumderived polysaccharide (Wang et al., 2017b), Momordica charantia (Xu et al., 2015), Talinum triangulare (Xu et al., 2015), Ocimum gratissimum (Livia et al., 2014), Citrus macroptera Montr (Uddin et al., 2014), Eugenia jambolana (Kishalay et al., 2015), Prunus cerasus L. (Fatima et al., 2017), Gaultheria trichophylla (Fiaz et al., 2017), Rhizo- phora mangle (Adolfo et al., 2017) and so on.

Elaeagnus angustifolia commonly refer to as" sliver berry", "Russian olive", "oleaster", "wild olive" and "qi li xiang" in mandarin belongs to Elaeagnus genus. The fruit from E. angustifolia contains higher content of polysaccharide which can reduce blood lipid and lower hypertension (Bendaikha et al., 2014). Furthermore, several researchers have reported that E. angustifolia polysaccharide have significant anti-oxidant capacity, anti-inflammatory capacity, anti-mutagenic capacity (Du et al., 2016; Hamidpour et al., 2017). Some experts researched the effect of E. angustifoli polysaccharides on immune functions of immunosuppressive mice and they found that E. angustifolia polysaccharides markedly increased the immunity function by increasing the spleen and thymus index of mice (Lian et al., 2009). However, hypoglycemic potential of E. angusso is far. Therefore, our research was undertaken to investigate the hypolipidemic effects of E. angustifolia polysaccharide on type 2 diabetic mice. 


\section{Materials and Methods}

\section{Chemicals and reagents}

Streptozotocin was purchased from the Sigma Chemical Company (USA). Disodium hydrogen phosphate and sodium dihydrogen phosphate were obtained from Beijing chemical company (China), and acarbose was gained from Bayer Health Care Company (China).

\section{Collection of plant material}

The ripe fruits of E. angustifolia were obtained from Gu lang Town, Gansu Province in China. They were crushed to $0.38 \mathrm{~mm}$ before use.

\section{Preparation of polysaccharide from $E$. angustifolia}

The powdered E. angustifolia $(0.5 \mathrm{~kg})$ was soaked in $95 \%$ ethanol in a tightly closed round bottom flask at $85^{\circ} \mathrm{C}$ for 2 hours in order to get rid of fat. The residue was filtered through Buchner funnel and then soaked in $2 \mathrm{~L}$ of sterile double-distilled water in (ammonium sulfate/ polyethylene glycol) and further heated at $95^{\circ} \mathrm{C}$ in water bath for 2 hours to ensure maximum yield of water soluble compounds. The liquid extract was then cooled and concentrated by using a rotary evaporator at $80^{\circ} \mathrm{C}$. The ethanol $(80 \%)$ was poured into the extract and put in the $4^{\circ} \mathrm{C}$ for 24 hours and then concentrated at 4,000 rpm for $15 \mathrm{~min}$ (Chen et al., 2015). The extraction solution was deproteinized by the Sevag method (Pan, 2015) repeated three times. The activated carbon powder was used for decolorization and the operation was repeated several times until no color remains (Yu et al., 2017). The dialysis bags were used to remove small molecule impurities (including monosaccharides, oligosaccharides and some salt ions, etc). As listed above, $83.7 \%$ purified E. angustifolia polysaccharide was obtained.

\section{Experiment animals}

Adult male mice (22-27 g) were obtained from the animal facility of the biomedicine unit, Lanzhou University. All the animals were housed in standard conditions with 12/12 hours light-dark cycle at a temperature of $25 \pm 5^{\circ} \mathrm{C}$ and a humidity of $35-60 \%$. All of them could get tap water and rodent chow ad libitum.

\section{Effect on blood glucose of normal mice}

The male mice $(n=40)$ were chosen and adapted to the experimental environment after a week. Then they were divided into 4 groups and each group had 10 mice. The normal control group were given an equal amount of citrate buffer whereas other three groups received $E$. angustifolia at three different concentrations (400, 600 and $800 \mathrm{mg} / \mathrm{kg}$ ) for 1 week. After fasted for 3 hours in the last administration, the blood was taken from the tail and blood glucose meter was used to determinate blood glucose level.

\section{Induction of diabetes}

A total of 80 healthy male mice were selected to adapt to the experimental environment. A week later, 70 were randomly selected and injected with freshly prepared streptozotocin $150 \mathrm{mg} / \mathrm{kg}$ (streptozotocin dissolved with citrate buffer with $\mathrm{pH}$ 4.3). The remaining 10 healthy mice used as the normal control group, were injected with equal amount of saline. After 72 hours, blood glucose levels were measured. Mice with blood glucose levels $\geq 16.7 \mathrm{mmol} / \mathrm{L}$ were considered diabetic and were used for the study (Junod, 1967).

\section{Experiment design}

The mice were divided into six groups with 10 mice in each group. Group I, mice were administered intragastrically with $0.9 \%$ physiological saline for 28 days (normal control); Group II, the diabetic mice were administered intragastrically with $0.9 \%$ saline for 28 days (negative control); Group III, the control mice were administered intragastrically with acarbose for 28 days (positive control); Group IV, the diabetic mice were administered intragastrically with E. angustifolia at $400 \mathrm{mg} / \mathrm{kg}$ for 28 days; Group V, diabetic mice were administered intragastrically with E. angustifolia at 600 $\mathrm{mg} / \mathrm{kg}$ for 28 days; Group VI, diabetic mice were administered intragastrically with E. angustifolia at 800 $\mathrm{mg} / \mathrm{kg}$ for 28 days.

\section{Effect on body weight, blood glucose and lipid levels}

During the experimental process, the weight of the experimental mouse was measured once a week. After four weeks, the blood sampling was taken from the eyeball and then measured the blood glucose level, blood lipids including high density lipoprotein cholesterol (HDL-C), total cholesterol as well as triglyceride were measured (Xiong et al., 2013).

\section{Statistical analysis}

Results were expressed as mean \pm standard deviation (SD). Data were analyzed by one-way analysis of variance (ANOVA) followed by Duncan's multiplerange test using the SPSS 17.0 statistical software program. Differences were considered significant at $\mathrm{p}<0.05$.

\section{Results}

\section{Effect on blood glucose level in diabetic mice}

Compared to the normal control group, the diabetic mice showed an obvious increase of blood glucose level over the completed period $(\mathrm{p}<0.05$; Table I). Results showed no significant difference among negative control group, positive control group and E. angustifolia treated groups in the first day. However, the blood glucose level of the positive control group and $E$. 
Table I

\section{Effect of E. angustifolia on blood glucose level} of diabetic mice

\begin{tabular}{|lrrr|}
\hline Group & \multicolumn{3}{c|}{ Blood glucose level (mmol/L) } \\
\cline { 2 - 4 } & 0 week & 2 weeks & 4 weeks \\
\hline Normal control & $6.4 \pm 0.7^{\mathrm{b}}$ & $6.1 \pm 1.0^{\mathrm{d}}$ & $6.3 \pm 0.1^{\mathrm{e}}$ \\
Negative control & $20.7 \pm 1.2^{\mathrm{a}}$ & $22.6 \pm 21^{\mathrm{a}}$ & $24.3 \pm 1.2^{\mathrm{a}}$ \\
Positive control & $20.6 \pm 0.9^{\mathrm{a}}$ & $18.6 \pm 1.5^{\mathrm{c}}$ & $15.0 \pm 1.1^{\mathrm{d}}$ \\
Extract $(400 \mathrm{mg} / \mathrm{kg})$ & $21.2 \pm 2.2^{\mathrm{a}}$ & $20.5 \pm 1.4^{\mathrm{b}}$ & $18.1 \pm 1.6^{\mathrm{b}}$ \\
Extract $(600 \mathrm{mg} / \mathrm{kg})$ & $21.0 \pm 1.8^{\mathrm{a}}$ & $20.5 \pm 1.5^{\mathrm{b}}$ & $16.5 \pm 1.6^{\mathrm{c}}$ \\
Extract $(800 \mathrm{mg} / \mathrm{kg})$ & $21.8 \pm 1.7^{\mathrm{a}}$ & $19.9 \pm 1.9^{\mathrm{b}}$ & $15.8 \pm 1.5^{\mathrm{cd}}$ \\
$\begin{array}{l}\text { Values represent the mean } \pm \text { standard error }(\mathrm{n}=10) . \text { Means followed } \\
\text { by different superscripts in the same column are significantly differ- } \\
\text { ent at }(\mathrm{p}<0.05)\end{array}$ \\
\hline
\end{tabular}

angustifolia treated groups were lower than that in the negative control group after two weeks of administration. The blood glucose level of the mice in the experimental group (except negative control group) continued to decrease, while negative control group showed an increasing trend. In the fourth week, the blood glucose level in E. angustifolia $(800 \mathrm{mg} / \mathrm{kg})$ group was $15.8 \mathrm{mmol} / \mathrm{L}$, which is $34.8 \%$ lower than that of negative control group. Above all, blood glucose level of E. angustifolia (800 mg/kg) group showed no significant difference $(\mathrm{p}>0.05)$ with that of positive control in the fourth week. It can be seen that $E$. angustifolia $(800 \mathrm{mg} / \mathrm{kg})$ group had a better effect on inhibiting blood glucose level.

\section{Effect on body weight in diabetic mice}

As shown in Table II, the body weight of diabetic mice in negative control group, positive control group and $E$. angustifolia groups decreased in the first two weeks. In addition, the body weight in diabetic mice was lower than that of in normal control. After two weeks of administration, the body weight of the positive control group and E. angustifolia groups were increased gradually, instead, it showed a continuous increase in the negative control group. In the fourth week, the body weight of the negative control group continually decreased which was the symptom of diabetes, however, the body weight of E. angustifolia $(800 \mathrm{mg} / \mathrm{kg})$ group was recovered to the began weight. These results indicated that E. angustifolia can alleviate the weight loss of diabetic mice.

\section{Effects on blood lipid in diabetic mice}

Due to abnormal metabolism of lipids, the accumulation of total cholesterol and triglyceride in diabetic patients increased, while HDL decreased
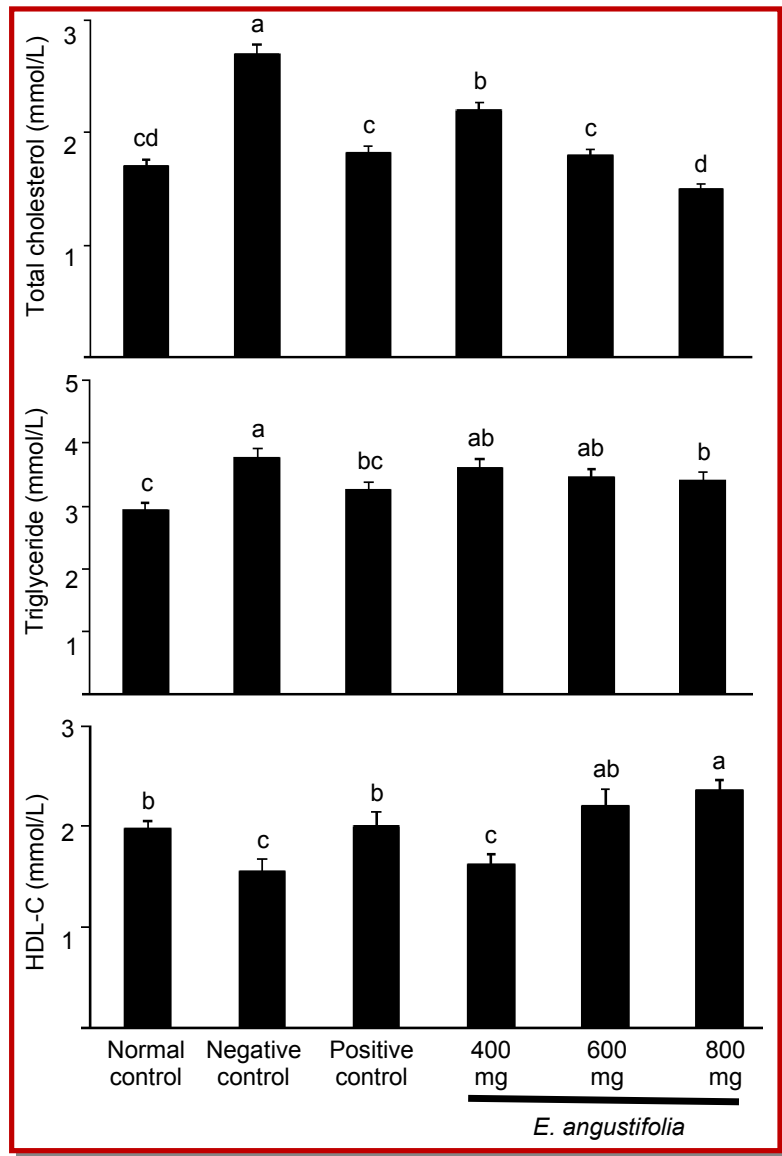

Figure 1: Effect of E. angustifolia on total cholesterol, triglyceride and HDL-C levels in diabetes mice. Different lowercase letters indicate significant differences between means $(\mathrm{p}<0.05)$

Table II

Effect of $E$. angustifolia on body weight of diabetic mice

\begin{tabular}{|lccccc|}
\hline \multicolumn{5}{c|}{ Body weight $(\mathrm{g})$} \\
\hline Group & 0 week & 1 week & 2 weeks & 3 weeks & 4 weeks \\
\hline Normal control & $24.9 \pm 1.5^{\mathrm{ab}}$ & $28.4 \pm 2.0^{\mathrm{a}}$ & $32.2 \pm 2.0^{\mathrm{a}}$ & $36.2 \pm 0.9^{\mathrm{a}}$ & $39.4 \pm 1.3^{\mathrm{a}}$ \\
Negative control & $24.5 \pm 1.8^{\mathrm{ab}}$ & $21.6 \pm 1.8^{\mathrm{d}}$ & $19.9 \pm 0.8^{\mathrm{d}}$ & $17.1 \pm 1.5^{\mathrm{d}}$ & $16.9 \pm 0.8^{\mathrm{e}}$ \\
Positive control & $24.1 \pm 1.5^{\mathrm{a}}$ & $23.7 \pm 1.8^{\mathrm{bc}}$ & $24.0 \pm 0.2^{\mathrm{b}}$ & $25.3 \pm 0.7^{\mathrm{b}}$ & $26.5 \pm 0.0^{\mathrm{b}}$ \\
Extract $(400 \mathrm{mg} / \mathrm{kg})$ & $23.9 \pm 1.1^{\mathrm{b}}$ & $22.5 \pm 2.1^{\mathrm{cd}}$ & $21.2 \pm 0.8^{\mathrm{c}}$ & $23.7 \pm 1.7^{\mathrm{c}}$ & $23.0 \pm 0.8^{\mathrm{d}}$ \\
Extract $(600 \mathrm{mg} / \mathrm{kg})$ & $24.8 \pm 1.7^{\mathrm{ab}}$ & $23.4 \pm 2.1^{\mathrm{bc}}$ & $22.2 \pm 1.2^{\mathrm{c}}$ & $23.5 \pm 0.5^{\mathrm{c}}$ & $23.3 \pm 0.8^{\mathrm{cd}}$ \\
Extract $(800 \mathrm{mg} / \mathrm{kg})$ & $24.7 \pm 1.8^{\mathrm{ab}}$ & $23.8 \pm 2.4^{\mathrm{b}}$ & $23.2 \pm 2.4^{\mathrm{b}}$ & $23.6 \pm 1.3^{\mathrm{c}}$ & $24.1 \pm 0.9^{\mathrm{c}}$ \\
Values represent the mean \pm standard error $(\mathrm{n}=10)$. Means followed by different superscripts in the same column are significantly \\
different at $(\mathrm{p}<0.05)$
\end{tabular}


(Wang et al., 2017a). The results in Figure 1 showed the effect of different doses of E. angustifolia on blood lipid levels of normal and diabetic male mice. The levels of total cholesterol and triglyceride negative control group were higher than those in other groups, and had the lower level of HDL-C which was a serious complication of diabetes mellitus. Compared with negative control group, the levels of total cholesterol and triglyceride in E. angustifolia $(400,600$ and $800 \mathrm{mg} / \mathrm{kg})$ groups were significantly lower. It is worth noting that total cholesterol in E. angustifolia $(800 \mathrm{mg} / \mathrm{kg})$ group was 1.5 $\mathrm{mmol} / \mathrm{L}$ which was lower than $1.8 \mathrm{mmol} / \mathrm{L}$ in positive control group. The HDL-C was higher in E. angustifolia $(800 \mathrm{mg} / \mathrm{kg})$ group among all the treated groups. It is obvious that diabetes mellitus symptoms are effectively alleviated by E. angustifolia treatments.

\section{Discussion}

In the present study, polysaccharide from E. angustifolia fruit was purified. The diabetic mice showed an obvious increase of blood glucose compared with normal control mice. Similar results were reported with the polysaccharide from Lilium lancifolium (Zhang et al., 2014). This result was similar to Guo et al. (2017) who found that fasting blood glucose of PPSC group was significantly lower compared with negative control. In addition, $15.8 \mathrm{mmol} / \mathrm{L}$ glucose level in E. angustifolia (800 $\mathrm{mg} / \mathrm{kg}$ ) group is lower than that reported by Wang et al. (2017b) who noted the blood glucose in PSD -H group was $17.0 \mathrm{mmol} / \mathrm{L}$. As known, streptozotocin can directly damage the pancreatic islet $\beta$-cells in mice, making it unable to normally secrete insulin thus cause the rise of blood glucose level. Results showed that $E$. angustifolia. fruit polysaccharide can significantly $(p<0.05)$ reduce blood glucose in diabetic mice, it's presumably due to reducing the damage of streptozotocin to pancreatic $\beta$-cells and enhancing the secretion of islets.

The initial loss of body weight in streptozotocininduced diabetic mice has explained by Jiang et al. (2013) who pointed out that the loss of body weight was consistent with the clinical symptom of patients with diabetes mellitus. The body weight in streptozotocininduced diabetic mice was lower than that of normal control, it could be due to protein dehydration and fat metabolism (Guo et al., 2017). Our results showed that body weight in E. angustifolia groups was increased gradually which was in line with Pan et al. (2014) who reported that the weight gain was increased in DHP, DOP, DNP and high dosages DNP groups of alloxaninduced diabetic mice and Guo et al. (2017) who noted that the PPSC group showed a higher increase in body weight of alloxanised mice than negative control. The body weight in E. angustifolia ( $800 \mathrm{mg} / \mathrm{kg}$ ) group was higher than that of in negative control group in the fourth week, it probably due to the improvement of glucose uptake and utilization in cells thus reducing the consumption of tissue protein and fat (Guo et al., 2017).

Our results showed lower levels of total cholesterol and triglyceride as well as higher HDL level in E. angustifolia groups compared with negative control group. Similarly, Fu et al. (2012) reported that ASP group could raise the ratio of $\mathrm{HDL} /$ total cholesterol and reduce the total cholesterol, triglyceride levels, especially at the dose of $200 \mathrm{mg} / \mathrm{mL}$. However, Wu et al. (2015) found that total cholesterol of Talinum triangulare polysaccharidestreated streptozotocin-induced diabetic mice showed no significant difference compared with negative control $(p>0.05)$ and higher than positive control. It is worth mentioning that total cholesterol in E. angustifolia $(800 \mathrm{mg} / \mathrm{kg}$ ) group was lower than that of in positive control group. This found was in line with Pan et al. (2017) who noted that $800 \mathrm{mg} / \mathrm{kg}$ corn silk polysaccharides showed lower total cholesterol than that of in positive control group.

\section{Conclusion}

E. angustifolia fruit polysaccharide has hypolipidemic effect presented in a significant reduction in total cholesterol, triglyceride and an improvement in HDL-C of diabetic mice.

\section{Ethical Issue}

All experimental process of animals were approved by the Ethics Committee for Animal Experimentation of the University, and carried out in accordance with the Regulations of Experimental Animal Administration issued by the State Committee of Science and Technology of People's Republic of China.

\section{Conflict of Interest}

The authors declare that there are no conflicts of interest.

\section{Acknowledgement}

This research work was supported by doctoral fund from Lanzhou University of Technology.

\section{References}

Alam F, Saqib QN. Antidiabetic potential of Gaultheria trichophylla in mice. Bangladesh J Pharmacol. 2017; 12: 29298.

Andrade-Cetto A, Escandón-Rivera SM, Torres-Valle GM, Quijano L. Phytochemical composition and chronic hypoglycemic effect of Rhizophora mangle cortex on STZ-NAinduced diabetic rats. Braz J Pharmacog. 2017; 27: 744-50.

Bendaikha S, Gadaut M, Harakat D, Magid A. Acylated flavonol glycosides from the flower of Elaeagnus angustifolia 
L. Phytochemistry 2014; 103: 129-36.

Casanova LM, da Silva D, Sola-Penna M, de Magalhães Camargo LM, de Moura Celestrini D, Tinoco LW, Costa SS. Identification of chicoric acid as a hypoglycemic agent from Ocimum gratissimum leaf extract in a biomonitoring in vivo study. Fitoterapia 2014; 93: 132-41.

Chen R, Li H, Li S, Jin C, Lu J. Extraction optimization: Preliminary characterization and immunological activity of polysaccharides from figs. Int J Biol Macromol. 2015; 72: 18594.

Du H, Chen J, Tian S, Gu H, Li N, Sun Y, Ru J, Wang J. Extraction optimization, preliminary characterization and immunological activities in vitro of polysaccharides from Elaeagnus angustifolia L. pulp. Carbohydr Polym. 2016; 151: 348-57.

Fu J, Fu J, Liu Y, Li R, Gao B, Zhang N, Wang B, Cao Y, Guo K, $\mathrm{Tu}$ Y. Modulatory effects of one polysaccharide from Acanthopanax senticosus in alloxan-induced diabetic mice. Carbohydr Polym. 2012; 87: 2327-31.

Guo Y, Li S, Li J, Ren Z, Chen F, Wang X. Anti-hyperglycemic activity of polysaccharides from calyx of Physalisalkekengi var. franchetii Makino on alloxan-induced mice. Int J Biol Macromol. 2017; 99: 249-57.

Hamidpour R, Hamidpour S, Hamidpour M, Shahlari M, Sohraby M, Shahlari N, Hamidpour R. Russian olive (Elaeagnus angustifolia L.): From a variety of traditional medicinal applications to its novel roles as active antioxidant, anti-inflammatory, anti-mutagenic and analgesic agent. J Tradit Complement Med. 2017; 7: 24-29.

Jana K, Bera TK, Ghosh D. Antidiabetic effects of Eugenia jambolana in the streptozotocin-induced diabetic male albino rat. Biomarkers Genomic Med. 2015; 7: 116-24.

Jiang S, Du P, An L, Yuan G, Sun Z. Anti-diabetic effect of Coptis Chinensis polysaccharide in high-fat diet with STZinduced diabetic mice. Int J Biol Macromol. 2013; 55: 118-22.

Junod A, Lambert AE, Orci L, Pictet R, Gonet AE, Renold AE. Studies of the diabetogenic action of streptozotocin. Proc Soc Exp Biol Med. 1967; 126: 201-05.

Kim HM, Kang JS, Kim JY, Park SK, Kim HS, Lee YJ, Yun J, Hong JT, Kim Y, Han SB. Evaluation of antidiabetic activity of polysaccharide isolated from Phellinus linteus in nonobese diabetic mouse. Int Immunopharmacol. 2010; 10: $72-78$.

Li RJ, Qiu SD, Chen HX, Tian H, Liu GQ. Effect of Astragalus polysaccharide on pancreatic cell mass in type 1 diabetic mice [J]. Zhongguo Zhong Yao Za Zhi. 2007; 32: 69-73.

Lian Y, Chen H, Li B, Yang J, Yuan J. Immunolo-regulation effect of Elaeagnus angustifolia L. Polysaccharides in immunosuppressive mice. J Anhui Agric Sci. 2009; 37: 748182.

Pan LH, Li XF, Wang MN, Zha XQ, Yang XF, Liu ZJ, Luo YB, Luo JP. Comparison of hypoglycemic and anti-oxidative effects of polysaccharides from four different Dendrobium species. Int J Biol Macromol. 2014; 64: 420-27.

Pan XF. Efficiency of protein removal from the polysaccharide extract of Dendrobium candidum Wall. ex Lindll using deproteinization Sevage method. Subtrop Agric Res. 2015; 11: 258-61.

Pan Y, Wang C, Chen Z, Li W, Yuan G, Chen H. Physicochemical properties and antidiabetic effects of a polysaccharide from corn silk in high-fat diet and streptozotocininduced diabetic mice. Carbohydr Polym. 2017; 164: 370-78.

Saleh FA, El-Darra N, Raafat K. Hypoglycemic effects of Prunus cerasus L. pulp and seed extracts on alloxan-induced diabetic mice with histopathological evaluation. Biomed Pharmacother. 2017; 88: 870-77.

Uddin N, Hasan MR, Hossain MM, Sarker A, Hasan AHMN, Islam AFMM, Chowdhury MMH, Rana MS. In vitro aamylase inhibitory activity and in vivo hypoglycemic effect of methanol extract of Citrus macroptera Montr. fruit. Asian Pac J Trop Biomed. 2014; 4: 473-79.

Wang D, Zhao X, Liu Y. Hypoglycemic and hypolipidemic effects of a polysaccharide from flower buds of Lonicera japonica in streptozotocin-induced diabetic rats. Int J Biol Macromol. 2017a; 102: 396-404.

Wang S, Lu A, Zhang L, Shen M, Xu T, Zhan W, Jin H, Zhang Y, Wang W. Extraction and purification of pumpkin polysaccharides and their hypoglycemic effect. Int J Biol Macromol. 2017; 98: 182-87.

Wang Y, Lin D, Wang X, Zhu W, Ye J, Li G, Ma Z, Deng X. The impact of a novel peach gum-derived polysaccharide on postprandial blood glucose control in streptozotocininduced diabetic mice. Int J Biol Macromol. 2017b; 98: 379-86.

Xiong WT, Gu L, Wang C, Sun HX, Liu X. Anti-hyperglycemic and hypolipidemic effects of Cistanche tubulosa in type 2 diabetic db/db mice. J Ethnopharmacol. 2013; 150: 935-45.

Xu W, Zhou Q, Yin JJ, Yao Y, Zhang JL. Anti-diabetic effects of polysaccharides from Talinum triangulare in streptozotocin (STZ)-induced type 2 diabetic male mice. Int J Biol Macromol. 2015; 72: 575-79.

Xu X, Shan B, Liao CH, Xie JH, Wen PW, Shi JY. Anti-diabetic properties of Momordica charantia $L$. polysaccharide in alloxan-induced diabetic mice. Int J Biol Macromol. 2015; 81: 538-43.

Yu XH, Liu Y, Wu XL, Liu LZ, Fu W, Song DD. Isolation, purification, characterization and immunostimulatory activity of polysaccharides derived from American ginseng. Carbohydr Polym. 2017; 156: 9-18.

Zhang T, Gao J, Jin ZY, Xu XM, Chen HQ. Protective effects of polysaccharides from Lilium lancifolium on streptozotocininduced diabetic mice. Int J Biol Macromol. 2014; 65: 436-40.

Author Info
Ya Wang (Principal contact)
e-mail: 524249316@qq.com

